\title{
DNA damage and expression profile of genes associated with nephrotoxicity induced by butralin and ameliorating effect of Arabic gum in female rats
}

\author{
Amel A. Refaie \\ National Research Centre \\ Salwa M. Kassem
National Research Centre \\ Wagdy K. B. Khalil \\ National Research Centre
}

Aziza B Shalby ( $\nabla$ drazizanrc@yahoo.com )

NRC: National Research Centre https://orcid.org/0000-0002-9021-1922

\section{Research Article}

Keywords: Arabic gum, Butralin, Renal function disorder, DNA damage, Kidney specific genes, Antioxidants

Posted Date: March 12th, 2021

DOI: https://doi.org/10.21203/rs.3.rs-280861/v1

License: (c) (i) This work is licensed under a Creative Commons Attribution 4.0 International License. Read Full License

Version of Record: A version of this preprint was published at Applied Biochemistry and Biotechnology on July 9th, 2021. See the published version at https://doi.org/10.1007/s12010-021-03607-8. 


\section{Abstract}

Nephrotoxicity induced by exposure to environmental pollution including herbicides is became global problem. Natural products are the prime alternative of scientific research as they express better medicinal activity and minor side effects compared with variety of synthetic drugs. This study was performed to evaluate the nephroprotective proficiency of Arabic gum against butralin-induced nephrotoxicity. Adult female rats were supplemented with Arabic gum (4.3 g/kg b.wt) and/or butralin $(312 \mathrm{mg} / \mathrm{L})$ in drinking water for 30 days. The results found that markers of serum kidney function, oxidative stress biomarkers, DNA damage and expression of kidney specific genes (Acsm2, ACE and ACE2) as well as histopathological examination in treated rats were conducted. Butralin-treated rats showed a rise in serum creatinine, BUN and MDA as well as decrease in activity of the antioxidant markers. In addition, butralin treatment increased the DNA damage, altered the expression levels of Acsm2, ACE and ACE2 and elevated histopathological lesions in kidney tissues. Pretreatment of Arabic gum prevented butralin-prompted degenerative changes of kidney tissues. The results suggested that the protective effect provided by Arabic gum on renal tissues exposed to the herbicide butralin could be attributed to enhancement of antioxidants and increase the free radicals scavenging activity in vivo.

\section{Introduction}

In the agriculture pesticides are considered as cost-effectively important and their use has related with increase of crop production globally. So, since 1950s using chemical compounds such as herbicides and insecticides for crop protection has coincided significantly to improve productivity [1]. In contrast, the perseverance of agricultural chemical residues within the environment may impress risk hazards to animals and humans [2]. Due to the widespread use of agrochemicals such as like herbicides a bad contamination occurs in our environment, so it is become essential to determine the potential toxicity of those chemicals on the surrounding organisms. These chemical compounds could induce biological, chemical and physical risks and may provoke genetic, biochemical and physiological alterations causing pathological impacts in the exposed organisms [3]. Several reports have been discussed the effect of variety of chemical substances inducing mutagenic potential effects in the affected organism. It has been found that such chemical substances could be found in pharmaceutical drugs, pesticides and food as well as in the mixtures of industrial and domestic effluents. It has been reported that these chemicals can induce harmful inheritable alteration in the genome of the organisms even these alterations are not expressed instantly [4]. Thus, various chemical compounds existing in the environment could provoke mutations in the human genome exposed to high contamination levels and may be risk for human health [5].

Wide utilization of herbicides in agriculture has increased the worldwide agricultural productivity. In the same time, several disadvantages have occurred due to herbicides consumption such as high cost of production, increase pathogens resistance and threat to environment and organisms' biodiversity [6]. Moreover, transfer the herbicides residues into rivers, waste water, and soil can affect the health of animals and human as well as other environmental compounds. So, several health problems of animals and humans were occurred due to increase of the herbicides residues exposure such as modulation of the immune system, endocrine disturbance, reproductive disorder, histopathological lesions and oxidative stress $[7,8]$.

The oxidative stress attributed to herbicide exposure in mammalian cells is almost to enhancement of ROS generation and inequity in the ratio of oxidant/antioxidant condition in the cells [9]. Consequently, ROS generation due to exposure to herbicides can enhance the lipid peroxidation, DNA and cell damage [10,11].

Cell protection against toxicity impacts of ROS generation is depending on role of enzymatic and non-enzymatic antioxidants $[12,13]$. Although kidney is considered as the essential organ in pesticide detoxification, its tissues are sensitive to ROS elevation, oxidative stress degree and the imbalance between antioxidant capability lead to disorder and damage of kidney tissues $[14,15]$. So, one of toxicity possible mechanisms of pesticides at sub-lethal doses are inducing oxidative stress in the form of ROS elevation $[14,16,17]$. From these pesticides are herbicides like dinitroaniline (such as 
butralin) which exhibiting several toxicological forms in the animals and humans. They are inducing endocrine disruption, kidney injury, kidney boundaries and mutagenic alterations [18].

Arabic gum is plant products as sticky and dried exudates from the Acacia senegal (Leguminosae) stems. It contains magnesium, calcium and potassium salts of the polysaccharides [19, 20]. Al-Majed et al. [21] and Elamin et al. [22] reported that Arabic gum has been used in public medicine to reduce recurrence of hemodialysis in interminable renal disorder patients. Moreover, Arabic gum exhibits diminish in urinary nitrogen discharge by urea removal expanding and decrease of serum urea in rats and humans $[23,24,25]$. Furthermore, Arabic gum has been found to protect against gentamicin-inducing nephrotoxicity [21]. They found that treatment of rats with Arabic gum prevented gentamicin-induced lipid peroxidation in renal tissues, improved kidney function and histological lesions [21].

As far for our knowledge, there are no published data with regard to the nephroprotective impact of Arabic gum against butralin intoxication. Along these lines, the current was conducted to study (a) the unfriendly impact of intense butralin exposure on rat's kidney toxicity; (b) the possible mitigating effect of Arabic gum against acute butralin intoxication in rats.

\section{Materials And Methods}

\section{Herbicide and kits}

Butralin (Amex® 48 \% EC) was gotten from CFPI (Compagnie Francaise de Produits Industriels) Agro SA, France. Serum kidney function and oxidative stress kits i.e. creatinine, urea, total protein, total antioxidant capacity, catalase, glutathione peroxidase and lipid peroxide were obtained from Biodiagnostic Co., Dokki, Giza, Egypt. Trizol was bought from Invitrogen (USA). The reverse transcription and PCR kits were obtained from Fermentas (USA). Arabic gum (pure) was purchased from SAGA company, Sudan. All other chemicals and reagents were gotten from tried and trusted companies.

\section{Animals and experimental setup}

Adult female rats weighing 136.4 $\pm 5.2 \mathrm{~g}$ were obtained from Animal Breeding House (ABH), National Research Center (NRC), Dokki, Giza, Egypt. Rats were preserved in specific cages, five female rats of each, at standard food and conditions in $\mathrm{ABH}$ lab. All animal groups in the $\mathrm{ABH}$ research facility were kept as per the Guide for the Care and Use of Laboratory Animals [26], which affirmed by NRC Local Ethical Review Committee.

Female rats were partitioned into four groups as follows: Group 1, animals were gotten water and filled in as control group; Group 2, rats got Arabic gum at concentration $4.3 \mathrm{~g} / \mathrm{kg}$ b.wt for 30 days [25]; Group 3, animals got Arabic gum plus butralin (312 mg/L) [27] in drinking water for 30 days.; Group 4: rats got butralin (312 mg/L) alone in drinking water related to the Acceptable Daily Intake (ADI, $0.5 \mathrm{mg} / \mathrm{kg}$ ) for rats [28]. During treatment duration rats were investigated for any harmfulness indications and mortality day by day for 30 days.

\section{Blood and organs samples}

After 30 days of treatment, adult female rats were fasted overnight and blood samples were collected. Animals were anesthetized using ethyl ether (1.9\%) and kidney tissues were removed after sacrificed by cervical dislocation. Blood samples were centrifuged (3000 rpm for ten min at $4{ }^{\circ} \mathrm{C}$ ), serum was separated and stored at $-20{ }^{\circ} \mathrm{C}$ for biochemical studies within 4 days. After cleaning of kidney from blood residual one part was kept in formalin (10\%) for histopathological examination. A piece of the second part of kidney tissues was homogenized in phosphate-buffered saline, centrifuged for $10 \mathrm{~min}$ at 10,000 rpm. The supernatant was used for oxidative stress analyses. Other pieces of the kidneys were used for genetic studies.

\section{Serum kidney function biomarkers}


Serum biomarkers creatinine and blood urea nitrogen (BUN) were determined by the methods of Tietz et al, [29] and Henry, [30], respectively.

\section{Oxidative stress markers in kidney tissue}

Oxidative stress biomarkers likes GPx, CAT, total antioxidant capacity (TAC) and MDA were determined by the methods of Nishikimi et al, (1972) [31], Abei, (1984) [32], Miller et al, [33] and Paglia and Valentine, [34], respectively.

\section{Comet Assay}

DNA damage in treated female rats using comet assay was performed according to Blasiak et al., [35]. Slides containing kidney samples were prepared and electrophoresis $(0.8 \mathrm{~V} / \mathrm{cm}, 300 \mathrm{mAmps})$ was carried out for 30 min to assess the DNA damage in 100 cell per each animal. The non-overlapping cells were randomly selected and were visually assigned a score on an arbitrary scale of $0-3$ based on apparent comet tail and relative quantity of DNA in the nucleus ("class 0 " exhibits normal cell and "class 3 " exhibits DNA damage with tail longer than $2 x$ the diameter of the nucleus).

\section{Gene expression analysis}

\section{Isolation of total RNA and reverse transcription reaction}

The total RNA of collected kidney samples of treated female rats was extracted using TRIzol® extraction reagent (Invitrogen). Subsequent to achievement of the RNA extraction, the pellets of the isolated RNA were kept in water containing DEPC. The isolated RNA was exposed to RNAse-free DNAse kit (Invitrogen, Germany) to break down the potential residues of the DNA [25]. Afterwards, the extracted RNA was divided in aliquots and kept under $-80{ }^{\circ} \mathrm{C}$ until use for reverse transcription.

To synthesize the cDNA copies of the kidney tissues of treated rats, synthesis kit of First Strand cDNA of Fermentas Company (RevertAidTM, MBI Fermentas) was utilized to reverse isolated RNA to cDNA through the reaction of reverse transcription (RT). The PCR program of the RT to obtain the cDNA copy was adjusted as follows: (a) 10 min at $25^{\circ} \mathrm{C}$; (b) 60 min at $42{ }^{\circ} \mathrm{C}$; and (c) 5 min at $95^{\circ} \mathrm{C}$. after termination of the RT reaction, the PCR tubes containing cDNA copies were kept at $-20^{\circ} \mathrm{C}$ up to use for qRT-PCR [36].

\section{Quantitative Real Time-PCR}

The synthesized cDNA copies of the kidney tissues were used for the qRT-PCR reaction using SYBR green kit (TaKaRa, Biotech. Co. Ltd.). Melting curve was performed for each reaction and specific studied gene. The Ct values of the qRT-PCR of investigated genes (Acsm2, Ace and Ace2) were normalized on those of the $\beta$-actin housekeeping gene (Table 1). The quantitative values of the tested genes under investigation to the housekeeping gene were assessed using $2^{-\triangle \Delta C T}$ method. 


\begin{tabular}{|c|c|c|}
\hline Gene & Forward & NCBI Reference \\
\hline \multirow[t]{2}{*}{ Acsm2 } & $\mathrm{F}:$ gag gtg gtg aag gca ttt gt & \multirow[t]{2}{*}{ NM_144748.1 } \\
\hline & R: gag cct tgg gag tct cac tg & \\
\hline \multirow[t]{2}{*}{ Ace } & F: gag cca tcc ttc cct ttt tc & \multirow[t]{2}{*}{ NM_012544.1 } \\
\hline & $\mathrm{R}:$ ggc tgc agc tcc tgg tat ag & \\
\hline \multirow[t]{2}{*}{ Ace2 } & F: gct aaa cat gat ggc cca ct & \multirow[t]{2}{*}{ NM_001012006.1 } \\
\hline & R: ccc aca gtc gaa ttc ctg tt & \\
\hline \multirow[t]{2}{*}{ GAPDH } & F: GGA TGC AGG GAT GAT GTT CT & \multirow[t]{2}{*}{ NM_017008.3 } \\
\hline & R: GAA GGG CTC ATT GAC CAC AGT T & \\
\hline
\end{tabular}

\section{Histopathological studies}

The kidney was dehydrated in alcohol and fixed in paraffin wax, and thick sections were cut and stained by hematoxylin and eosin (H\&E). Slides examined for histopathological alterations (10 field areas of each section) by a light microscope (Olympus BX50). The histopathological changes in kidney tissues were scored as follows: normal appearance (-), mild (+), moderate (++) and severe (+++).

\section{Statistical analysis}

All data obtained from biochemical and molecular genetics studies were expressed as Means \pm SEM. The data were investigated with the Statistical Package for Social Sciences (SPSS 0.26 for windows). The outcomes were dissected utilizing one route investigation of difference (ANOVA) trailed by Duncan's test for examination between various treatment gatherings and statistical significance was set at $P<0.05$.

\section{Results}

\section{Effect of butralin and Arabic gum in serum biomarkers and kidney weight}

In the current effort, butralin was administrated to a female rat via drinking water for 30 days at a concentration $312 \mathrm{mg} / \mathrm{L}$ which corresponding to dose equaled to $0.5 \mathrm{mg} / \mathrm{kg}$ based on water intake of female rats. No mortality of toxicity has been recorded in butralin-treated female rats after 30 days of treatment. There was no significant change in food consumption or water intake during the experimental period (30 days) of all treated female rats. The relative kidney weight was significantly decreased in female rats exposed to butralin at dose $(0.5 \mathrm{mg} / \mathrm{kg})$ (Table 2). In present study, serum creatinine and BUN were significantly increased after exposure to butralin as compared with the control group $(P<0.005)($ Table 1$)$. Pretreatment of 
animals with Arabic gum and concomitantly with Arabic gum significantly reduced the rise in the level of BUN and creatinine.

Table 2

Kidney dysfunction biomarkers in female rats exposed to Arabic gum and butralin.

\begin{tabular}{|llll|}
\hline Treatments & $\begin{array}{l}\text { Creatinine } \\
(\mathrm{mg} / \mathrm{dl})\end{array}$ & BUN(mg/dl) & Relative kidney weight (\%) \\
\hline Control & $0.83 \pm 0.006^{\mathrm{c}}$ & $30.34 \pm 0.34^{\mathrm{c}}$ & $0.95 \pm 0.005^{\mathrm{a}}$ \\
\hline Arabic gum & $0.96 \pm 0.023^{\mathrm{bc}}$ & $34.14 \pm 0.21^{\mathrm{bc}}$ & $0.92 \pm 0.012^{\mathrm{a}}$ \\
\hline Arabic gum + Butralin & $1.01 \pm 0.027^{\mathrm{b}}$ & $35.74 \pm 0.56^{\mathrm{b}}$ & $0.86 \pm 0.007^{\mathrm{b}}$ \\
\hline Butralin & $1.17 \pm 0.006^{\mathrm{a}}$ & $44.70 \pm 0.43^{\mathrm{a}}$ & $0.73 \pm 0.011^{\mathrm{c}}$ \\
\hline Values are means $\pm \mathrm{SE}, \mathrm{n}=5$; values having the different letters are significantly different from each other. \\
\hline
\end{tabular}

\section{Oxidative stress biomarkers in rats exposed to butralin and treated with Arabic gum}

In butralin-treated rats showed a rise in oxidative stress (MDA) in their kidney tissues and decreased activity of the antioxidant markers (GPx, CAT and TAC) that associated with antioxidant defense and detoxification mechanisms in hepatocytes (Table 3). Pretreatment with Arabic gum attenuated the butralin-induced oxidative damage. Hence, pretreatment with Arabic gum significantly restored the oxidative stress and elevated the total antioxidant markers activities in the group treated with Arabic gum plus butralin to the normal values.

Table 3

Oxidative stress biomarker in kidney tissue of female rats exposed to butralin and treated with Arabic gum.

\begin{tabular}{|lllll|}
\hline Treatments & $\begin{array}{l}\text { CAT } \\
\text { (u/mg protein) }\end{array}$ & $\begin{array}{l}\text { GPX } \\
\text { (u/gprotein) }\end{array}$ & $\begin{array}{l}\text { TAC } \\
(\mathrm{mmol} / \mathrm{l})\end{array}$ & $\begin{array}{l}\text { MDA } \\
\text { (nmol/mg protein) }\end{array}$ \\
\hline Control & $38.49 \pm 0.40^{\mathrm{a}}$ & $6.22 \pm 0.045^{\mathrm{a}}$ & $0.81 . \pm 0.007^{\mathrm{a}}$ & $0.44 . \pm 0.016^{\mathrm{c}}$ \\
\hline Arabic gum & $37.85 \pm 0.53^{\mathrm{a}}$ & $5.74 \pm 0.032^{\mathrm{a}}$ & $0.83 \pm 0.011^{\mathrm{a}}$ & $0.47 . \pm 0.003^{\mathrm{c}}$ \\
\hline Arabic gum + Butralin & $33.90 \pm 0.21^{\mathrm{b}}$ & $3.59 \pm 0.025^{\mathrm{b}}$ & $0.62 \pm 0.012^{\mathrm{b}}$ & $0.75 . \pm 0.014^{\mathrm{b}}$ \\
\hline Butralin & $30.41 \pm 0.52^{\mathrm{c}}$ & $1.82 \pm 0.027^{\mathrm{c}}$ & $0.46 \pm 0.006^{\mathrm{c}}$ & $1.06 . \pm 0.017^{\mathrm{a}}$ \\
\hline Values are means $\pm \mathrm{SE}, \mathrm{n}=5$; values having the different letters are significantly different from each other. \\
\hline
\end{tabular}

\section{Assessment of DNA damage}

DNA damage determination in kidney samples of female rats exposed to butralin and Arabic gum is presented in Table 4. The results explained that rate of DNA damage in kidney samples of rats treated with Arabic gum was quite similar to that in control untreated rats. However, treatment of female rats with butralin increased the rate of DNA damage with high significant differences $(P<0.01)$ compared with that in control rats. In contrast, treatment of female rats exposed to butralin improved the rate of DNA damage in kidney samples compared with that in female rats exposed to butralin alone. 
Table 4

Visual score of DNA damage in tissue samples collected from treated animals with butralin and/or Arabic gum.

\begin{tabular}{|c|c|c|c|c|c|c|c|c|}
\hline \multirow[t]{2}{*}{ Treatment } & \multicolumn{3}{|c|}{ No. of cells } & \multicolumn{4}{|c|}{ Class $^{\star *}$} & \multirow{2}{*}{$\begin{array}{l}\text { DNA damaged cells \% } \\
\text { (Mean } \pm \text { SEM) }\end{array}$} \\
\hline & No of samples & Analyzed* & Comets & 0 & 1 & 2 & 3 & \\
\hline Control & 4 & 400 & 29 & 371 & 25 & 4 & 0 & $7.25 \pm 0.63^{c}$ \\
\hline Arabic gum & 4 & 400 & 27 & 373 & 24 & 3 & 0 & $6.75 \pm 0.48^{c}$ \\
\hline Arabic gum + Butralin & 4 & 400 & 55 & 345 & 31 & 14 & 10 & $13.76 \pm 0.25^{b}$ \\
\hline Butralin & 4 & 400 & 93 & 307 & 32 & 26 & 35 & $23.27 \pm 0.76^{a}$ \\
\hline
\end{tabular}

\section{Expression alteration of genes associated with nephrotoxicity}

The expression profile of genes (Acsm2, Ace and Ace2) involving with nephrotoxicity in female rats exposed to butralin and treated with Arabic gum is illustrated in Fig. 1-3. Fig. 1 showed that expression levels of Acsm2 gene in kidney tissues of female rats exposed to butralin were decreased significantly compared to those in control animals. However, female rats supplemented with Arabic gum revealed high expression levels of Acsm2 gene similar to those in untreated control rats. Moreover, treatment of butralin-exposed rats with Arabic gum increased significantly the levels of Acsm2 gene compared to those in female rats exposed to butralin alone.

Fig. 2 and 3 showed that expression levels of Ace and Ace 2 genes in kidney samples of female rats exposed to butralin were increased significantly compared to those in control animals. In contrast, animals supplemented with Arabic gum revealed low expression levels of Ace and Ace 2 genes like to those in health control rats. Furthermore, treatment of butralin-exposed rats with Arabic gum decreased significantly the levels of Ace and Ace2 genes compared to those in animals exposed to butralin alone.

\section{Histopathological findings}

Butralin induced histological changes in kidney of female rats including the cortico medullary junction and focal haemorrhages and degeneration in the tubular lining epithelium (Table 5 \& Fig. 4). However, rats of control group and group treated with Arabic gum showed normal kidney tissues with the normal renal architecture formed of malpighian orpuscle which contain the glomerulus formed of capillary loops separated from Bowman capsule by Bowman Space. Also, the proximal convoluted tubules lined by simple cuboidal with microvilli as it begin at the capsule and distal convoluted tubules. The Arabic gum plus butralin treated group showed focal inflammatory cells infiltration in between the degenerated tubules at the cortex. 
Table 5

Histopathological changes in the kidney tissue of female rates exposed to butralin and treated with Arabic gum based on scoring severity of injury.

\begin{tabular}{|c|c|c|c|c|}
\hline Observation & Control & Arabic gum & Arabic gum + Butralin & Butralin \\
\hline Inflammatory cells in the portal area & - & - & + & ++ \\
\hline Focal necrosis in the kidney parenchyma & - & - & - & ++ \\
\hline Diffuse kupffer & - & - & - & - \\
\hline \multicolumn{5}{|l|}{ proliferation } \\
\hline $\begin{array}{l}\text { Normal }(-) \text {, minimal }(+) \text {, mild }(++) \text {, moder } \\
\text { butralin }(G 4) \text {. }\end{array}$ & ontrol ( & Arabic gun & Arabic gum plus butra & ), and \\
\hline
\end{tabular}

\section{Discussion}

In agribusiness utilization of herbicides to control weeds has been is extensively increased worldwide. However, using these synthetic chemicals in uncontrolled way can cause negative impacts on non-target living beings including aquatic environments [37]. In the current study, butralin was orally administrated to female rats via drinking water for 30 days at a concentration $312 \mathrm{mg} / \mathrm{L}$ which equal to dose $0.5 \mathrm{mg} / \mathrm{kg}$ based on water intake of the animals. In this study, no mortality of butralin toxicity has been recorded in exposed female rats throughout or after treatment duration. Also, there was no observed significant change in food consumption or water intake during the experimental period of all treated female rats. However, using relative kidney weight as toxicological biomarker in this study explained that there were significant differences in female rats exposed to butralin compared with control rats. The rise in relative kidney weights could be attributed to the nephrotoxicity of butralin inducing kidney damage as reported by Mossa et al. [15]. Additionally, organ weight variations were observed by other dinitroaniline herbicides in rats and rabbits [18].

The current study showed significant elevation in serum creatinine and BUN of rats exposed to butalin as compared with the control rats. This expansion in creatinine level in female rats might be due to the impedance of the glomerular capacity and/or tubular function in the kidneys [38]. The expanded degrees of creatinine and BUN accumulation in the blood show a difficulty in the kidney function in getting rid of these substances. Refaie et al. [39] found a raised degree of urea in blood was associated with increase of protein catabolism in the mammalian body. They suggested that BUN level is increased due to increasing the alkylated urea derivatives in rats exposed to insecticide paralethrin. Therefore, the current study suggests that expansion of urea and creatinine levels in the serum of female rats is associating with histological alterations inducing a reduction in the glomerular filtration rate as a result of butralin intoxication.

Oxidative stress is a vital sign for understanding the mechanism of pesticide toxicity because is associating with alteration of oxidant/ antioxidant status and defence pathway $[16,40]$. In this study, butralin-exposed rats showed a rise in MDA (as an oxidative stress marker) and decrease in activity levels of the antioxidant markers (GPx, CAT and TAC). A previous study reported that paraquat (as it related to dinitroaniline) reduces the activity levels of GPx, and CAT [41].

Female rats exposed to butralin increased significantly the rate of DNA damage compared with that in control rats. Our previous wok indicated that the ROS formation was raised significantly with the exposure to butralin in a dose-dependent manner [27]. It can be suggest that butralin motivated oxidative stress inducing DNA damage by generation of ROS in exposed rats. Naturally, free radicals are created during cellular biological reactions in equilibrium with the biological antioxidant systems [42; 43]. 
Acsm2 gene is considered as a kidney-specific "KS" gene in mammals [44, 45]. They reported that Acsm2 gene is expressed when the function of renal tissues became mature in kidneys of rats. Moreover, Gomez et al. [46] and Watanabe et al. [45] indicated that Acsm2 expression is likely associated to the growth and maturational alterations occurring in the kidney cells after few weeks' postpartum in rats and mice. In present work we found that expression levels of Acsm2 gene were reduced in rats exposed to butralin. This reduction in Acsm2 levels is might be probably associated with the histopathological lesions in proximal tubules induced by butralin as observed in our study. ACE function regulates RAS (renin-angiotensin system) which is coincided with renal disease [47, 48, 49]. The RAS system is working in breakdown of the Angll profibrotic peptide into Ang- 1-7 $(50,51]$. So, ACE and ACE2 genes are greatly expressed in the diseased kidney [51]. In the same line, the current results found that rats exposed to butralin showed low expression levels of ACE and ACE2 genes compared with control rats.

Pretreatment with Arabic gum attenuated the toxic effect of butralin-induced oxidative damage in female rats. Hence, pretreatment with Arabic gum significantly restored the GPX, CAT and TAC levels near to those in control rat's values. Several studies indicated that Arabic gum has been found to act as antioxidant product in addition to its useful effects on kidney function $[52,53,54]$. The present results found that Arabic gum exhibited significant reduction in MDA and increase in GPx, CAT and TAC activities in kidney tissue of the Arabic gum plus butralin group. These results are consistent with the previous evidence of Al Za'abi et al. [55], who proposed the main mechanism for the beneficial action of Arabic gum in adenineinduced kidney disease through its antioxidant properties. The antioxidation induced by Arabic gum might be one of the most likely mechanisms supplying to its beneficial effect against kidney injury. This antioxidant effect of Arabic gum was established previously by in vitro studies, which showed that Arabic gum had a dose-dependent scavenging of free radicals produced enzymatically and nonenzymatically [56]. Hence, Arabic gum could have the ability to inhibit ROS generation induced by herbicides $[10,11]$ due to suppression of MDA. Therefore, it could be suggested that Arabic gum scavenges butralin free-radicals generation and, in turn, inhibits MDA-induced DNA damage in renal tissues, which has been recommended to protect renal tissue damage induced by butralin. The present results indicated that the expression profile of Acsm2, ACE and ACE2 genes is altered in rats exposed to butralin which is likely attributed to the damage occurred in renal tissues. So, renal tissue protection by treatment of Arabic gum could be also associated with reduce the expression alteration of Acsm2, ACE and ACE2 genes induced by butralin. Therefore, the protective effect provided by Arabic gum on renal tissues exposed to the herbicide butralin could be attributed to enhancement of antioxidants and increase the free radicals scavenging activity in vivo.

\section{Conclusion}

In vivo exposure to butralin induced MDA, decreased antioxidant enzymes activities, elevated DNA damage and changed the mRNA levels of kidney specific genes. These negative actions of butralin on kidney tissues could be attributed to increase free radical formation as reported in our previous work [27]. Treatment of female rats with Arabic gum suppressed the toxicity effects induced by butralin. So, the protective effect provided by Arabic gum on renal tissues exposed to the herbicide butralin could be attributed to enhancement of antioxidants and increase the free radicals scavenging activity in vivo.

\section{Declarations}

\section{Conflict of Interests:}

The authors declare that they have no conflict of interests.

\section{Ethical Approval:}

Compliance with Ethical Standards 


\section{Informed Consent}

Informed consent was obtained from all individual participants included in the study.

\section{Authors Contributions}

All authors have contributed equally in this work.

\section{Availability of data and materials}

All data and materials are available.

\section{ACKNOWLEDGMENTS}

The authors are thankful for the National Research Centre-Cairo, Egypt for supporting this study.

\section{References}

1. Beddington, -J. Global food and farming futures, Philos Trans R Soc Lond B Biol Sci. (2010) 2767. DOI: 10.1098/rstb.2010.0181.

2. Dallegrave, -E., Mantese, F. D., Oliveira, R. T., Andrade, A. J., Dalsenter, P. R., \& Langeloh, A. (2007). Pre-and postnatal toxicity of the commercial glyphosate formulation in Wistar rats. Archives of Toxicology, 81(9), 665-673. DOI 10.1007/s00204-006-0170-5.

3. Arnaiz, -S. L., Llesuy, S., Cutrín, J. C., \& Boveris, A. (1995). Oxidative stress by acute acetaminophen administration in mouse kidney. Free Radical Biology and Medicine, 19(3), 303-310. https://doi.org/10.1016/0891-5849(95)00023-Q.

4. Vogel, -W. H., Miller, J., DeTurck, K. H., \& Routzahn, B. K. Jr. (1984). Effects of psychoactive drugs on plasma catecholamines during stress in rats. Neuropharmacology, 23(9), 1105-1108. DOI:10.1016/0028-3908(84)90136-9.

5. Langie, -S. A. S., Koppen, G., Desaulniers, D., Al-Mulla, F., Al-Temaimi, R., Amedei, A., Azqueta, A., Bisson, W. H., Brown, D. G., Brunborg, G., Charles, A. K., Chen, T., Colacci, A. M., Darroudi, F., Forte, S., Gonzalez, L., Hamid, R. A., Knudsen, L. E., Leyns, L., Salsamendi, A. L. C., Memeo, L., Mondello, C., Mothersill, C., Olsen, A. K., Pavanello, S., Raju, J., Rojas, E., Roy, R., Ryan, E. P., Ostrosky-Wegman, P., Salem, H. K., Scovassi, A. I., Singh, N., Vaccari, M., Van Schooten, F. J., Valverde, M., Woodrick, J., Zhang, L., van Larebeke, N., Kirsch-Volders, M., \& Collins, A. R. (2015). Causes of genome instability: the effect of low dose chemical exposures in modern society. Carcinogenesis, 36(1), S61-S68.

DOI:10.1093/carcin/bgv031.

6. Khan, -M. A., Marwat, K. B., Amin, A., Nawaz, A., \& Khan, H. (2012). Soil solarization: an organic weed management approach in cauliflower. Communications in Soil Science and Plant Analysis., 43(13), 1847-1860. https://doi.org/10.1080/00103624.2012.684822.

7. Badr, -A. M. Organophosphate toxicity: updates of malathion potential toxic effects in mammals and potential treatments, Environmental Science and Pollution Research, (2020) 26036-26057. DOI:10.1007/s11356-020-08937-4.

8. Samir, -D., Selma, R. M. O., \& Asma, S. The Effect of Herbicide Metribuzin on Environment and Human: A Systematic Review, Pharmaceutical and Biosciences Journal. 8(4) (2020) 10-15. DOI: http://dx.doi.org/10.20510/ukjpb/8/i4/1593522789.

9. Banerjee, -P., \& Bhattacharya, J. (2019). Impact of Oxidative stress on Infertility, with emphasis on infertility management strategie. Global Journal of Fertility and Research., 4(1), 010-018.

DOI:http://dx.doi.org/10.17352/gjfr.0000.

10. Agrawal, -A., \& Sharma, B. (2010). Pesticides induced oxidative stress in mammalian systems. Int J Biol Med Res, 1(3), 90-104.

https://www.biomedscidirect.com/36/pesticides_induced_oxidative_stress_in_mammalian_systems_a_review/archives. 
11. Braunersreuther, -V., \& Jaquet, V. (2012). Reactive oxygen species in myocardial reperfusion injury: from physiopathology to therapeutic approaches. Current pharmaceutical biotechnology, 13(1), 97-114.

DOI:10.2174/138920112798868782.

12. Vidyasagar, -J., Karunakar, N., Reddy, M. S., Rajnarayana, K., Surender, T., \& Krishna, D. R. (2004). Oxidative stress and antioxidant status in acute organophosphorous insecticide poisoning. Indian journal of pharmacology, 36(2), 76. http://www.bioline.org.br/pdf?ph04029.

13. Cheradid, -T., Guessoum, M., Study of risk factors and predictive markers of Chronic kidney disease (CKD) in Djamaa Hemodialysis Patients, and assessment of water quality effect (major risk factor) on kidney function in rats Wistar. University of Eloued DSpace, (2019) http://dspace.univ-eloued.dz/handle/123456789/4150.

14. Mansour, -S. A., \& Mossa, A. T. H. (2010). Oxidative damage, biochemical and histopathological alterations in rats exposed to chlorpyrifos and the antioxidant role of zinc. Pesticide Biochemistry and Physiology, 96(1), 14-23. https://doi.org/10.1016/j.pestbp.2009.08.008.

15. Mossa, -A. T. H., Swelam, E. S., \& Mohafrash, S. M. (2015). Sub-chronic exposure to fipronil induced oxidative stress, biochemical and histopathological changes in the kidney and kidney of male albino rats. Toxicology reports, 2, 775784. https://doi.org/10.1016/j.toxrep.2015.02.009.

16. Mansour, -S. A., \& Mossa, A. T. H. (2009). Lipid peroxidation and oxidative stress in rat erythrocytes induced by chlorpyrifos and the protective effect of zinc. Pesticide Biochemistry and Physiology, 93(1), 34-39. https://doi.org/10.1016/j.pestbp.2008.09.004.

17. Mansour, -S. A. K., \& Gamet-Payrastre, L. (2016). Ameliorative effect of vitamin $E$ to mouse dams and their pups following exposure of mothers to chlorpyrifos during gestation and lactation periods. Toxicology and Industrial Health, 32(7), 1179-1196. https://doi.org/10.1177/0748233714548207.

18. Byrd, -R. A., Marham, J. K., \& John, L. (1994). Developmental toxicity of dinitroaniline herbicides in rats and rabbits: Trifluralin. Journal of Toxicological Sciences, 26, 181-190. https://doi.org/10.1093/toxsci/26.2.181.

19. Dauqan, -E., \& Abdullah, A. (2013). Utilization of gum arabic for industries and human health. American Journal of Applied Sciences, 10(10), 1270-1279. DOl:https://doi.org/10.3844/ajassp.2013.1270.1279.

20. Mohammed, -A. M. E. Estimation of the active components in gum arabic collected from Western Sudan, International Journal of Science and Rese., 6(3) (2017) DOI:10.21275/ART20171695.

21. Al-Majed, -A. A., Mostafa, A. M., Al-Rikabi, A. C., \& Al-Shabanah, O. A. (2002). Protective effects of oral Arabic gum administration on gentamicin- induced nephrotoxicity in rats. Pharmacol Res., 46(5), 445-451. doi:10.1016/s1043661802001251.

22. Elamin, -S., Alkhawaja, M. J., Bukhamsin, A. Y., Idris, M. A. S., Abdelrahman, M. M., Abutaleb, N. K., \& Housawi, A. A. (2017). Gum Arabic Reduces C-Reactive Protein in Chronic Kidney Disease Patients without Affecting Urea or Indoxyl Sulfate Levels. International Journal of Nephrology. https://doi.org/10.1155/2017/9501470.

23. Ramsammy, -L., Ling, K. Y., Josepovitz, C., Levine, R., \& Kaloyanides, G. J. (1985). Effect of gentamicin on lipid peroxidation in rat renal cortex. Biochem Pharmacol., 34(21), 3895-3900. DOI:10.1016/0006-2952(85)90441-1.

24. Salahudeen, -A. K., Clark, E. C., \& Nath, K. A. (1985). Hydrogen peroxide-induced renal injury. A protective role for pyruvate in vitro and in vivo. J Clin Invest., 88(6), 1886-1893. https://doi.org/10.1172/JCI115511.

25. Said, -A. M., Atwa, S. A. E., \& Khalifa, O. A. Ameliorating effect of gum arabic and lemongrass on chronic kidney disease induced experimentally in rats, Bulletin of the National Research Centre, (2019) 43-47. https://doi.org/10.1186/s42269019-0.

26. -NRC. (1996). Guide for the care and use of laboratory animals, National Academic Research Council. Washington, DC: Acad. Press. http://www.nap.edu.

27. Refaie, -A. A., Ramadan, A., Sabry, N. M., Khalil, W. K. B., \& Mossa, A. T. H. (2020). Over-gene expression in the apoptotic, oxidative damage and liver injure in female rats exposed to butralin. Environmental Science and Pollution Research, 27, 
31383-31393. doi:10.1007/s11356-020-09416-6.

28. Tomlin, -C. D. S., The Pesticide Manual, The British Crop Protection Council (17 edition ed.). London, UK. (2015). ISBN: 9781901396881.

29. Tietz, -N. M., Pruden, E. L., Siggaard-Andersen, O., Electrolytes. In: Burtis CA, Ashwood ER, editors. Tietz textbook of clinical chemistry. Philadelphia: WB Saunders Company, (1994) 1354-1374. ISBN: 0721644724.

30. Henry, -R. J., Clinical chemistry. Principles and techniques. 2nd ed.New York: Harper and Row Publishers. (1974). ISBN: $00614118179780061411816 \$ 4$.

31. Nishikimi, -M., Rao, N. A., \& Yagi, K. (1972). The occurrence of superoxide anion in the reaction of reduced phenazine methosulfate and molecular oxygen. Biochemical and Biophysical Research Communications., 46(2), 849-854. https://doi.org/10.1016/S0006-291X(72)80218-3.

32. Aebi, -H. Catalase in vitro, Methods Enzymol. 105 (1984) 121-126.DOI: 10.1016/s0076-6879(84)05016-3.

33. Miller, -N. J., Rice-Evans, C., Davies, M. J., Gopinathan, V., \& Milner, A. (1993). A novel method for measuring antioxidant capacity and its application to monitoring the antioxidant status in premature neonates. Clin Sci (Lond)., 84, 407-412. DOI:10.1042/cs0840407.

34. Paglia, -D. E., \& Valentine, W. N. (1967). Studies on the quantitative and quali- tative characterization of erythrocyte glutathione peroxidase. J Lab Clin Med., 70(1), 158-135. doi:10.1007/s40200-020-00615-z.

35. Blasiak, -J., Arabski, M., Krupa, R., Wozniak, K., Zadrozny, M., Kasznikcki, J., Zurawska, M., \& Drzewoski, J. (2004). DNA damage and repair in type 2 diabetes mellitus. Mutat Res, 554(1-2), 297-304. DOI:10.1016/j.mrfmmm.2004.05.011.

36. Khalil, -W. K. B., Booles, H. F., Hafiz, N. A., \& El-Bassyouni, G. E. (2018). Ameliorative effects of brachidontes variabilis calcium carbonate against bone loss in ovariectomized rats. Int J Pharm, 14, 477-487. DOI:10.3923/ijp.2018.477.487.

37. Nwani, -C. D., Nagpure, N. S., Kumar, R., Kushwaha, B., Kumar, P., \& Lakra, W. S. (2011). Mutagenic and genotoxic assessment of atrazine-based herbicide to freshwater fish Channa puntatus (Bloch) using micronucleus test and single cell gel electrophoresis. Environmental Toxicology and Pharmacology, 31, 314-322. doi:10.1016/j.etap.2010.12.001.

38. Menez, -S., \& Parikh, C. R. (2019). Assessing the health of the nephron in acute kidney injury: biomarkers of kidney function and injury. Curr Opin Nephrol Hypertens., 28(6), 560-566. doi:10.1097/MNH.0000000000000538.

39. Refaie, -A. A. E. R., Ramadan, A., \& Mossa, A. T. H. (2014). Oxidative damage and nephrotoxicity induced by prallethrin in rat and the protective effect of Origanum majorana essential oil. Asian Pac J Trop Med., 7(1), S506-S513. doi:10.1016/S1995-7645(14)60282-0.

40. Mossa, -A. T. H., Rasoul, M. A. A., \& Mohafrash, S. M. (2017). Lactational exposure to abamectin induced mortality and adverse biochemical and histopathological effects in suckling pups. Environmental Science and Pollution Research, 24(11), 10150-10165. DOI:10.1007/s11356-017-8600-x.

41. Tan, -D., Wang, Y., Bai, B., Yang, X., \& Han, J. (2015). Betanin attenuates oxidative stress and inflammatory reaction in kidney of paraquat-treated rat. Food Chem Toxicol, 78, 141-146. DOI:10.1016/j.fct.2015.01.018.

42. Pham-Huy, -L. A., He, H., \& Pham-Huy, C. (2008). Free radicals, antioxidants in disease and health. Int J Biomed Sci., IJBS., 4, 89-96. PMID: 23675073.

43. Wang, -S., Guo, W., \& Ren, J. (2016). Stress signaling in paraquat-induced target organ toxicity. React Oxyg Species, 1 , 131-140. DOI:10.20455/ros.2016.827.

44. Hilgers, -K. F., Nagaraj, S. K., Karginova, E. A., Kazakova, I. G., Chevalier, R. L., Carey, R. M., Pentz, E. S., \& Gomez, R. A. Molecular cloning of KS, a novel rat gene expressed exclusively in the kidney, Kidney Int., 54 (1998) 1444-1454, doi: 10.1046/j.1523-1755.1998.00143.x. DOI: 10.1046/j.1523-1755.1998.00143.x.

45. Watanabe, -H., Paxton, R. L., Tolerico, M. R., Nagalakshmi, V. K., Tanaka, S., Okusa, M. D., Goto, S., Narita, I., Watanabe, S., Sequeira-Lopez, M. L. S., Gomez, R. A., Expression of Acsm2, a kidney-specific gene, parallels the function and maturation of proximal tubular cells, American Journal of Physiology-Renal Physiology, 319 (4) (2020) F603-F611. DOI: 10.1152/ajprenal.00348.2020.

Page $12 / 17$ 
46. -Gomez, R. A., Sequeira Lopez, M. L., Fernandez, L., Cherñavvsky, D. R., \& Norwood, V. F. (1999). The maturing kidney: development and susceptibility. Ren Fail, 21, 283-291. doi:10.3109/08860229909085090.

47. Donoghue, -M., Hsieh, F., Baronas, E., Godbout, K., Gosselin, M., Stagliano, N., Donovan, M., Woolf, B., Robison, K., Jeyaseelan, R., Breitbart, R. E., \& Acton, S. (2000). A novel angiotensin-converting enzyme-related carboxypeptidase (ACE2) converts angiotensin I to angiotensin 1-9. Circulation Research, 87, E1-E9. DOI:10.1161/01.res.87.5.e1.

48. Tipnis, -S. R., Hooper, N. M., Hyde, R., Karran, E., Christie, G., \& Turner, A. J. (2000). A human homolog of angiotensinconverting enzyme: cloning and functional expression as a captopril-insensitive carboxypeptidase. Journal of Biological Chemistry, 275, 33238-33243. DOI:10.1074/jbc.M002615200.

49. Burrell, -L. M., Johnston, C. I., Tikellis, C., \& Cooper, M. E. (2004). ACE2, a new regulator of the renin-angiotensin system. Trends in Endocrinology and Metabolism, 15, 166-169. DOI:10.1016/j.tem.2004.03.001.

50. Ferrario, -C. M. (2006). Angiotensin-converting enzyme 2 and angiotensin-(1-7): an evolving story in cardiovascular regulation. Hypertension, 47, 515-521. DOI:10.1161/01.HYP.0000196268.08909.fb.

51. Tallant, -E. A., \& Clark, M. A. Molecular mechanisms of inhibition of vascular growth by angiotensin-(1-7), Hypertension, 42 (2003) 574-579. DOI: 10.1161/01.HYP.0000090322.55782.30.

52. Ali, -B. H., Al-Husseni, I., Beegam, S., Al-Shukaili, A., Nemmar, A., Schierling, S., Queisser, N., \& Schupp, N. (2013a). Effect of gum arabic on oxidative stress and inflammation in adenine-induced chronic renal failure in rat. PLoS One. DOI:10.1371/journal.pone.0055242.

53. Ali, -B. H., Al-Salam, S., Za'abi, M. Al, Waly, M. I., Ramkumar, A., Beegam, S., Al-Lawati, I., Adham, S. A., \& Nemmar, A. (2013b). New model for adenine-induced chronic renal failure in mice, and the effect of gum acacia treatment thereon: comparison with rats. J Pharmacol Toxicol Methods, 68(3), 384-393. DOI:10.1016/j.vascn.2013.05.001.

54. Hammad, -F. T., Al Salam, S., Nemmar, A., Ali, M., \& Lubbad, L. The Effect of Arabic Gum on Renal Function in Reversible Unilateral Ureteric Obstruction, Biomolecules, 9 (2019) 25. DOI: 10.3390/biom9010025.

55. Za'abi, -M. A., Busaidi, M. Al, Yasin, J., Schupp, N., Nemmar, A., \& Ali, B. H. (2015). Development of a new model for the induction of chronic kidney disease via intraperitoneal adenine administration, and the effect of treatment with gum acacia thereon. Am J Transl Res, 7(1), 28-38. PMCID: PMC4346521.

56. Abd-Allah, -A. R., Al-Majed, A. A., Mostafa, A. M., Al-Shabanah, O. A., Din, A. G., \& Nagi, M. N. (2002). Protective effect of Arabic gum against cardiotoxicity induced by doxorubicin in mice: a possible mechanism of protection. $\mathrm{J}$ Biochem $\mathrm{Mol}$ Toxicol., 16(5), 254-259. DOI:10.1002/jbt.10046.

\section{Figures}




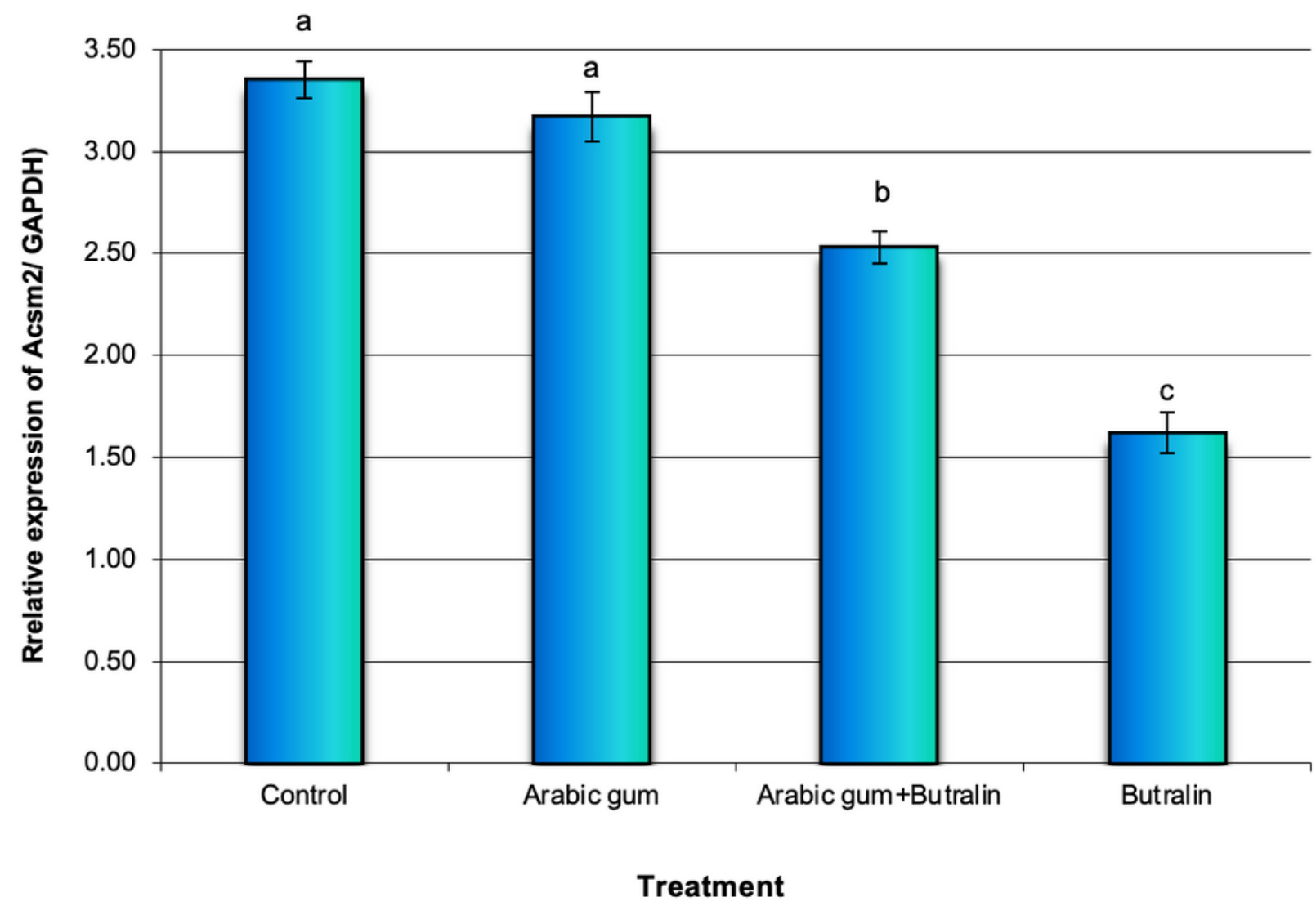

Figure 1

Expression levels of Acsm2 gene in kidney samples female rats exposed to butralin and treated with Arabic gum. Data are presented as mean \pm SEM. a,b,c followed by different superscripts are significantly different $(P \leq 0.05)$. 


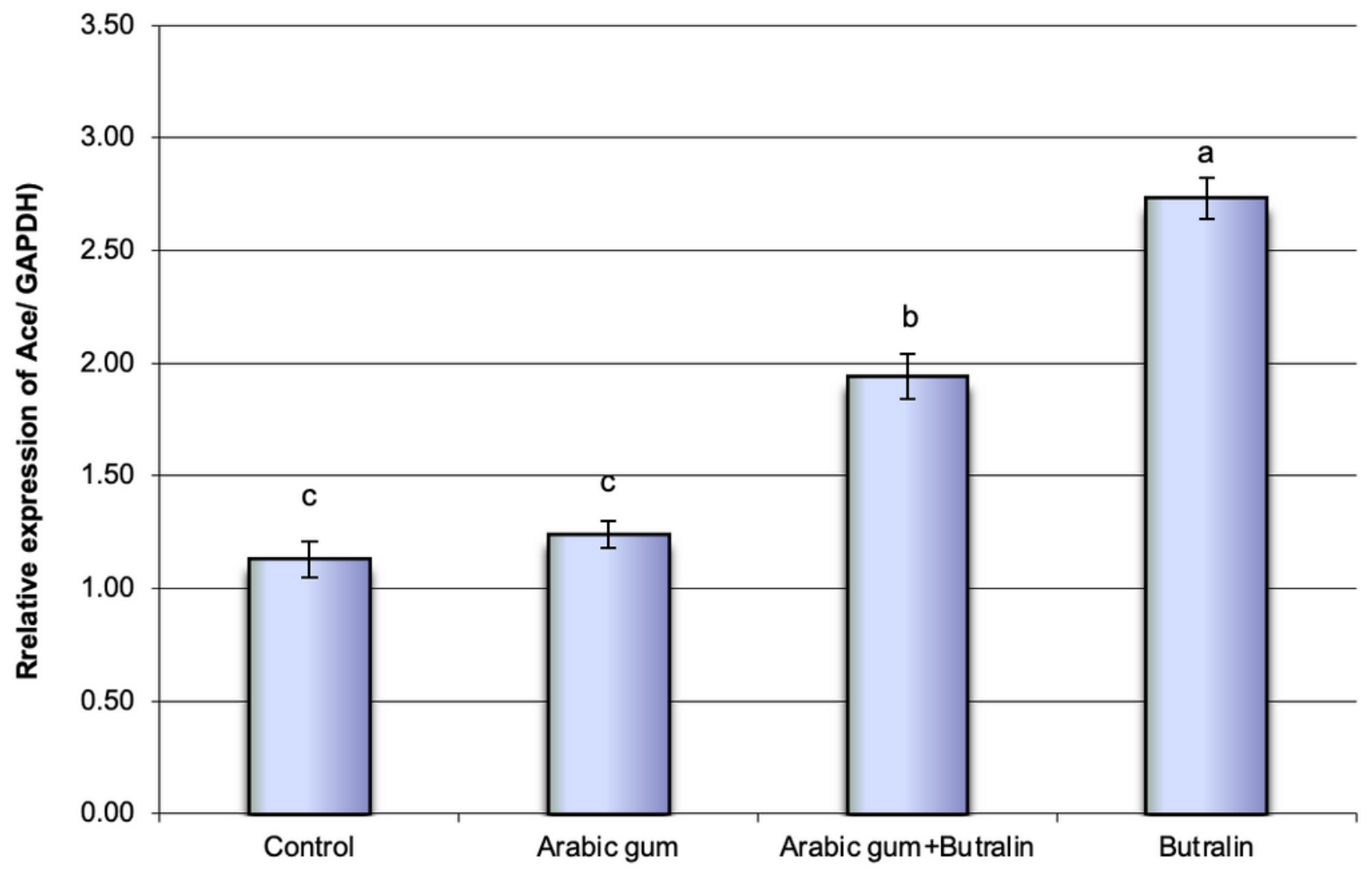

Treatment

Figure 2

Expression levels of Ace gene in kidney samples female rats exposed to butralin and treated with Arabic gum. Data are presented as mean \pm SEM. a,b,c followed by different superscripts are significantly different $(P \leq 0.05)$. 


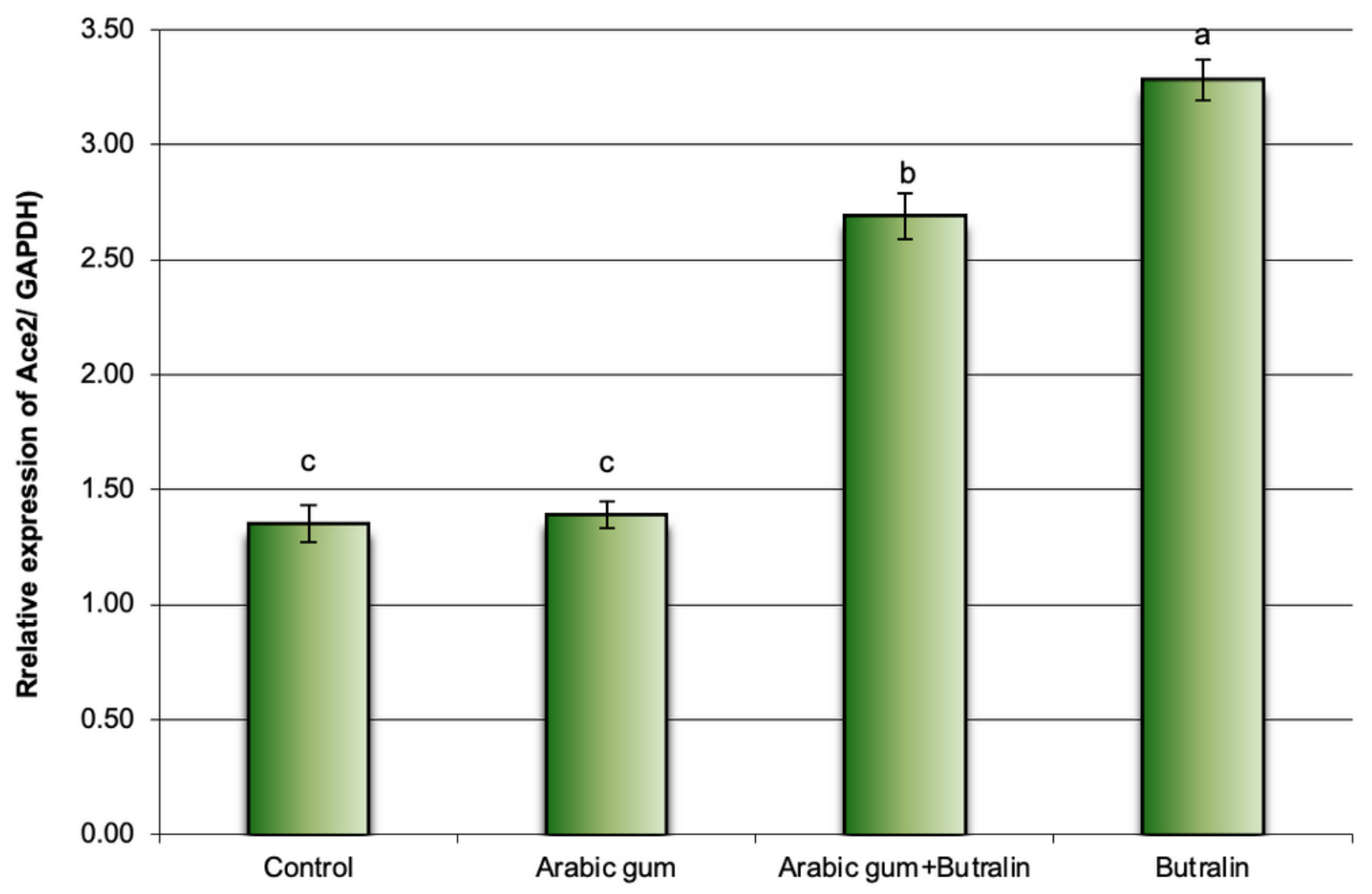

Treatment

Figure 3

Expression levels of Ace2 gene in kidney samples female rats exposed to butralin and treated with Arabic gum. Data are presented as mean \pm SEM. a,b,c followed by different superscripts are significantly different $(P \leq 0.05)$. 


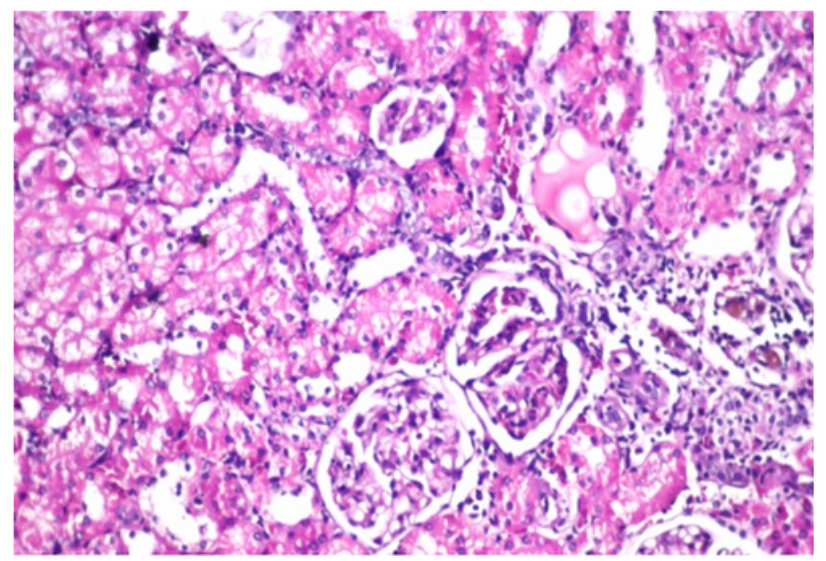

A

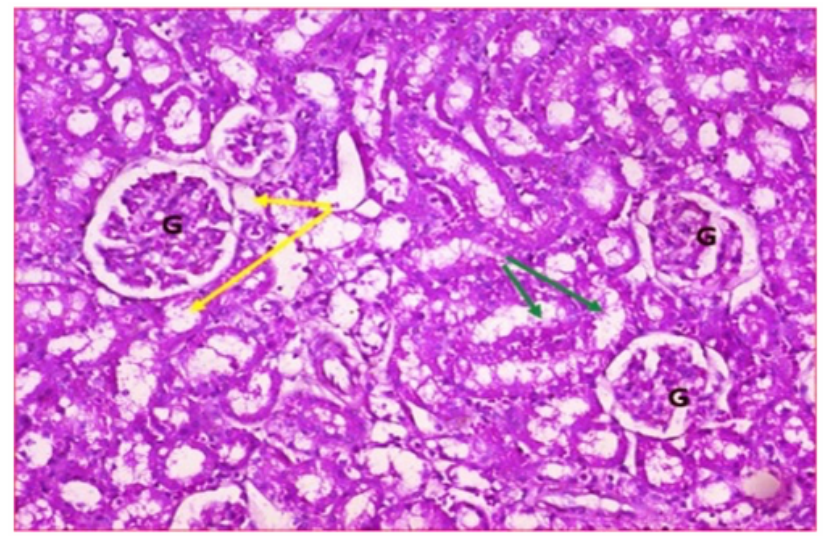

C

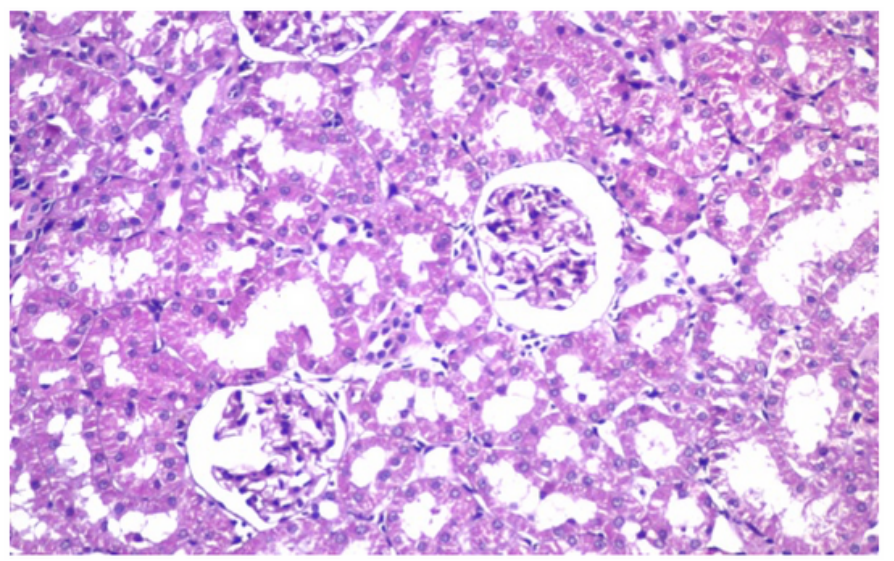

\section{B}

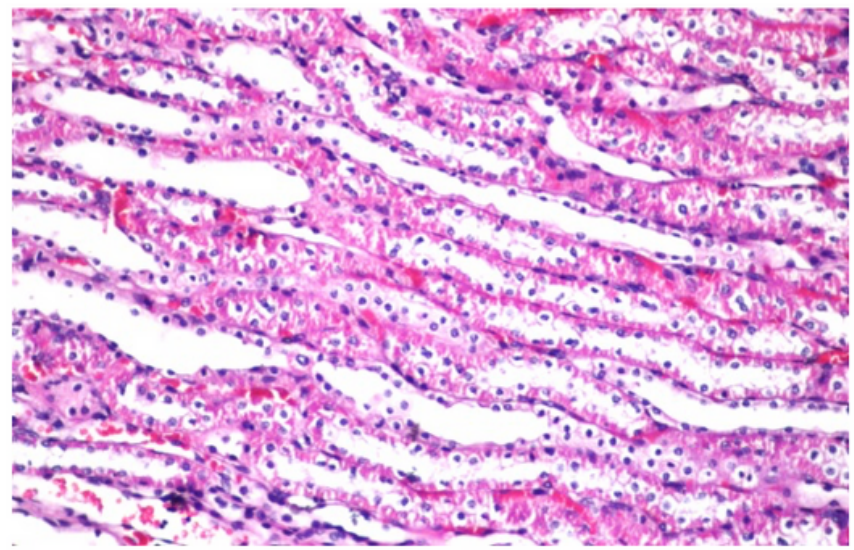

D

\section{Figure 4}

Photomicrography of kidney sections (Hand E,100X) showing normal kidney tissue in control group (A) and Arabic gumtreated group (B) with the normal renal architecture formed of malpighian orpuscle which contain the glomerulus formed of capillary loops separated from Bowman capsule by Bowman Space. The proximal convoluted tubules lined by simple cuboidal with microvilli as it begin at the capsule and distal convoluted tubules. Arabic gum plus butralin treated group (C) showing focal inflammatory cells infiltration in between the degenerated tubules at the cortex. Butralin treated group (D) showing the cortico medullary junction and focal haemorrhages, degeneration in the tubular lining epithelium.

\section{Supplementary Files}

This is a list of supplementary files associated with this preprint. Click to download.

- Graphicalabstract.docx 